$\xi=-1$

\title{
Policy Implementation in Realizing the Effectiveness of Disaster Management
}

\author{
Jusman Iskandar ${ }^{1 *}$, Ummu Salamah $^{2}$, Nonah Patonah ${ }^{3}$ \\ ${ }^{1,3}$ Department of Public Administration, Universitas Garut, Indonesia \\ ${ }^{2}$ Department of Social Welfare, Universitas Pasundan, Indonesia \\ *Corresponding Author E-Mail: Jusman.Iskandar@Uniga.Ac.Id
}

\begin{abstract}
A natural disaster is an undesirable event and it can happen anytime. The government should be present to decrease the consequences of natural disaster, so it is necessary to make public policy and coordination between government agencies to handle a natural disaster. The purpose of this study is to analyze the influence of the implementation of disaster management policy towards coordination between regional work units in realizing the effectiveness of disaster management. The research methodology used is a quantitative method with path analysis technique. The research was conducted in Regional Disaster Relief Agency of Garut District (Indonesia) with 73 respondents. The results showed that the disaster management policy has a positive and significant effect on the coordination between regional work units in realizing the effectiveness of disaster management. The research finding showed that the good implementation of policy can be performed through improving coordination between Regional Work Units to realize the effectiveness of disaster management.
\end{abstract}

Keywords: coordination; disaster management; effectiveness; policy

\section{Introduction}

Indonesia is a country regarded prone to disaster. Natural disasters can arise as a result of nature or the result of the human excessive exploitation of the environment ${ }^{1}$. With its unique geographical position, Indonesian archipelago is located at the confluence of three tectonic giant plates and lied between Asian and Australia continents, the Indian and the Pacific Oceans. It also consists of \pm 17,000 islands mostly facing the high seas with a coastline of over $81,000 \mathrm{~km}$. The geographical position makes Indonesia prone to volcanic eruptions and earthquakes, tidal waves affected by the tsunami and extreme weather conditions that potentially cause flooding, landslides, and drought. Based on disaster records, almost all the world's natural disaster have ever occurred in Indonesia and every natural disaster caused casualties.

As a matter of fact that disaster relief has gained serious attention from national and regional governments in Indonesia. A lot of attempts were done toward better disaster management. The series of disasters occurring in Indonesia, especially in 2004 and 2005, has arisen an awareness of developing more proactive, thorough, and fundamental new attitudes in responding disaster. Reactive attitude and disaster management patterns are seen no longer adequate. Disaster management patterns have a new dimension with the issuing Law No. 24 The year 2007 on Disaster Management, followed by some related implementing rules. The new dimensions of rules related to disaster management are as follows:

a. Disaster management as holistic and proactive efforts is initiated on disaster risk reduction, emergency response, and rehabilitation and reconstruction.

b. Disaster management as efforts jointly done by the stakeholders with their complementary roles and functions.

c. Disaster management as part of the development process that realizes resilience to disaster.
The above policies are also followed up with the establishment of National Disaster Relief Agency (BNPB) followed by the development of other policies in province and district/ city on strategy, and disaster relief operation in accordance with the direction of policy development at the national level. Based on observation and interview with several parties, the author assumed that the effectiveness of disaster management in Garut District was still not optimal, as indicated by the following aspects:

a. Uneven distribution of logistical assistance in times of disaster;

b. Poor understanding of disaster management policy, such as overlapping disaster management that must be improved;

c. Lack of resources owned by organizations that implement disaster management policies, in this case, Regional Disaster Relief Agency of Garut District that copes with disasters effectively and efficiently;

d. Lack of supporting facilities and infrastructure in implementing disaster management policies as well as incomplete simple, clear and easy supporting technical instructions so that policy can be optimally done.

Based on the problem background above, the authors have an interest in doing research related to entitled: "The influence of Disaster Management Policy Implementation toward Coordination between Regional Work Unit in Actualizing Disaster Management Effectiveness"

\section{Methodology}

The method used in this research is a descriptive method with survey techniques. The descriptive research method is a method that describes or elaborates the phenomena of the issues examined at the present time in order to find out the ways of problemsolving in which the result is implemented after investigation 
activities. Survey technique is done in a research that takes a sample from a population by questionnaire as a means of collecting primary data to analyze symptoms or observed phenomena.

To see the objective condition of research objects, the researcher determined the operation of research variables, which is structured to facilitate the steps in finding and collecting data from respondents based on the research theories, concepts, propositions, assumptions, and variables defined. The application of research variables is presented in Table 1.

The respondents in this research are 73 people of the heads of Quick Response Team (QRT) representing 27 Regional Work Units in Garut District, 4 people of QRT as an element agency that plays a role in disaster management, and 42 heads of sub-district in Garut District. Data collection technique used is a documentary study and field study. Data analysis technique used to answer research hypothesis is a statistical analysis of path analysis model Furthermore, in order to maintain the objectivity of research, the research result verification with the result of literature study, observation, and the interview is carried out as in result and discussion ${ }^{23}$.

\section{Results and Discussion}

This study examined the empirical evidence on the influence of the implementation of disaster management policy. The analyzed research paradigm is presented in Figure 1.

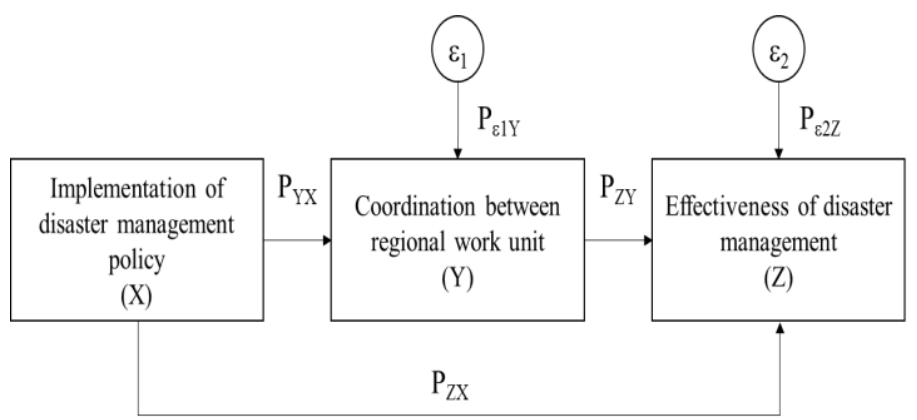

Fig. 1: Research Paradigm

\subsection{Result}

The research finding presents the result of the statistical calculation as shown in the following Table 2.

Table.1: Operation of Research Variables

\begin{tabular}{|c|c|c|c|}
\hline No & Variable & Dimension & Indicator \\
\hline \multirow[t]{8}{*}{1} & \multirow{8}{*}{$\begin{array}{l}\text { Implementation of } \\
\text { Management Policy (X) } \\
\text { (Winarno, 2012) }\end{array}$} & \multirow{3}{*}{$\begin{array}{l}\text { 1. Organization Dimension of Policy } \\
\text { Executive }\end{array}$} & a. Resources formation \\
\hline & & & b. Resources Regulation \\
\hline & & & c. Management methods \\
\hline & & \multirow[t]{2}{*}{ 2. Interpretation of Policy Executive } & a. $\quad$ Policy Conformity \\
\hline & & & b. $\quad$ Policy clarity \\
\hline & & \multirow[t]{3}{*}{ 3. Application of Policy Executive } & $\begin{array}{l}\text { a. Supporting technical guidelines for policy } \\
\text { implementation }\end{array}$ \\
\hline & & & b. Budget support for implementation \\
\hline & & & c. Infrastructure support \\
\hline \multirow[t]{12}{*}{2} & \multirow{12}{*}{$\begin{array}{l}\text { Coordination between Regional } \\
\text { Work Unit (Y) } \\
\text { (Iskandar, Managemen Publik, 2016) }\end{array}$} & \multirow[t]{2}{*}{ 1. Units in Organization } & $\begin{array}{l}\text { a. The formation of the coordination team of } \\
\text { disaster management }\end{array}$ \\
\hline & & & $\begin{array}{l}\text { b. The involvement of non-government/ private } \\
\text { element and foreign institutions in disaster } \\
\text { relief }\end{array}$ \\
\hline & & \multirow[t]{2}{*}{ 2. Resources and potential } & a. Human Resource Knowledge and Skills \\
\hline & & & b. Work facilities \\
\hline & & \multirow[t]{2}{*}{ 3. Activity Motion } & a. Disposition \\
\hline & & & b. $\quad$ Setting \\
\hline & & \multirow[t]{2}{*}{ 4. Indivisibility } & a. Unity of action \\
\hline & & & b. Communication \\
\hline & & \multirow[t]{2}{*}{ 5. Harmony } & a. $\quad$ Order \\
\hline & & & b. Conformity \\
\hline & & \multirow[t]{2}{*}{ 6. Same direction } & a. Guidance in policy implementation \\
\hline & & & b. $\quad$ Targeting \\
\hline \multirow[t]{13}{*}{3} & \multirow{13}{*}{$\begin{array}{l}\text { Effectiveness } \quad \text { of } \quad \text { Disaster } \\
\text { Management (Z) (Iskandar, 2015) }\end{array}$} & \multirow[t]{2}{*}{ 1. Basic Policy } & a. $\quad$ Planning \\
\hline & & & b. Goal \\
\hline & & \multirow[t]{3}{*}{ 2. $\quad$ Strategy clarity } & a. $\quad$ Strategy formulation \\
\hline & & & b. Strategy implementation \\
\hline & & & c. $\quad$ Strategy evaluation \\
\hline & & \multirow[t]{3}{*}{ 3. Organizing Organization Resources } & a. Suitability of Human Resources \\
\hline & & & b. Technology \\
\hline & & & c. Facilities and infrastructure \\
\hline & & \multirow[t]{3}{*}{ 4. Activity implementation } & a. Activity grouping \\
\hline & & & b. Delegation of authority \\
\hline & & & c. $\quad$ Supervision \\
\hline & & \multirow[t]{2}{*}{ 5. Result } & a. Implementation of work program \\
\hline & & & b. Public satisfaction \\
\hline
\end{tabular}




\begin{tabular}{|c|c|c|c|c|c|}
\hline Main Hypothesis & $\begin{array}{c}\text { Path } \\
\text { coefficient }\end{array}$ & $\mathbf{F}_{\text {value }}$ & $\mathbf{F}_{\text {dist }}$ & Determinant & $\begin{array}{l}\text { Relation } \\
\text { meaning }\end{array}$ \\
\hline $\begin{array}{l}\text { The Influence of Policy Implementation toward Coordination between Regional } \\
\text { Work Unit in Realizing Disaster Management Effectiveness }\end{array}$ & 0,7884 & 37,77 & 6,90 & 0,6215 & Significant \\
\hline Sub Hypothesis & $\begin{array}{c}\text { Path } \\
\text { coefficient }\end{array}$ & $t_{\text {value }}$ & $t_{\text {dist }}$ & Determinant & $\begin{array}{l}\text { Relation } \\
\text { meaning }\end{array}$ \\
\hline $\begin{array}{l}\text { The Influence of Policy Implementation toward Coordination between Regional } \\
\text { Work Unit }\end{array}$ & 0,8773 & 15,4035 & 1,9949 & 0,7697 & Significant \\
\hline $\begin{array}{l}\text { The influence of Policy Implementation toward the Effectiveness of Disaster } \\
\text { Management }\end{array}$ & 0,4712 & 3,3140 & 1,9949 & 0,3633 & Significant \\
\hline $\begin{array}{l}\text { The Influence of Coordination between the Regional Work Units toward the } \\
\text { Effectiveness of Disaster Management }\end{array}$ & 0,3418 & 2,8392 & 1,9949 & 0,2582 & Significant \\
\hline
\end{tabular}

The research finding showed that the implementation of disaster management policy simultaneously and partially has the positive and significant influence to the coordination between the Regional Work Unit in realizing the effectiveness of disaster management.

\subsection{Discussion}

This study analyzed public policy, from which public policy is defined as the application of a public policy through the program, activity, action, or performance in a mechanism tied to a particular system ${ }^{3}$. Based on the research finding, that not optimal implementation variable of disaster management policy is related to the implementation of disaster management policy in Garut District which is not supported by the ability of adequate resources, training/ technological training implemented in order to increase inadequate human resources, the unclear job division of disaster relief in Garut, the structure of disaster management in Garut District that still need improving, not all disaster reports in Garut are followed up by the entire fixed goals, work procedures of disaster management in Garut District have not properly implemented, the ready funds of disaster management in Garut District is not easy spending, disaster management in Garut has not been supported by the adequate facilities availability (work devices, websites, media), and the adequate infrastructure availability (information center, mobility). Therefore, it is suggested to conduct more intensive training/ technological training for the employees Regional Work Unit Garut and other employees involved in the team.

In fact, information technology can be built to lighten human complex tasks to become simpler ${ }^{456}$, including natural disasters management. In natural disasters relief, for example, Geographic Information System (GIS) based-application can be made. GISbased application is map-based information technology organized in computer hardware, software, geographic data, methods, and personnel efficiently designed to obtain, store, update, manipulate, analyze, and display all forms of geographically referenced information ${ }^{7}$, so that evacuation or even logistics distribution pattern for the victims of natural disasters may work effectively and efficiently.

Quick Response Team and the executive of disaster management policy, society, and education and business institutions are expected to establish competent employees, to increase community competence, and create a resilient district to disaster. The instructors of training should be professional who can present interesting material to make training participants enjoy and understand the topics of training/ technological training which are followed by a test to measure to what extent the presented material can understand by the participants of training; making a clear job division and the reorganization of the job procedures of disaster management; improving the structure of disaster management in Garut District so that every agency and related parties have their respective duties to avoid overlapping; proposing local governments for ready fund of Disaster Relief in Garut District to be easily cashed in the times of disaster; proposing local governments to improve networking website in the countryside so that website utilization for disaster management can be optimized; proposing additional mobility infrastructure to local governments so that the mobilization of disaster management work more smoothly; following up every disasters report in Garut immediately after the report was received in order to minimize losses resulting from the disaster; increasing community participation, education, and business institutions in disaster management at pre-disaster, time of disaster and post-disaster, considering that disaster management is not only the government task but also multi parties task.

Coordination between Regional Work Units (RWU) is related to the executors of RWU who are not able to arrange job schedule optimally in the case of disasters happening in Garut and implement disaster management priorities in Garut District that has not been optimally implemented. Thus, it is recommended to arrange schedules in RWU and disaster management activities at the time of disaster and make the preventive action in applying disaster management priorities. Some disasters can be prevented such as landslide, flood (in certain cases). Violence conflict is certainly involved in the kind of threat that may be prevented if the potential conflict can be detected early and treated properly. It is necessary to understand disaster symptoms considering that Indonesia geographically and socially has so many threats.

The effectiveness of disaster management constitutes the strategy formulated to achieve an unclear mid-term goal, the implementation of activities in each area has not been implemented properly, the head of executive delegates some of his jobs to the head of the division, and the head of the division delegate some of his jobs to the head of the section. Therefore, it is suggested to formulate a clear strategy to achieve the mid-term goal.

The formulated strategy should be very clear in how it is implemented, who will do it, when does it apply and so on; the head initiates communication with the executive element about the obstacles in implementing tasks and provides solutions to the problems they face; the head delegates some of his job to his subordinate officers to make job implementation lighter; executors should not hesitate to communicate with their leader in carrying out the tasks assigned to them, because without good communication, there is no problem solving for every obstacle they encounter in doing their jobs; executors should increase their competencies to do their job well. Developing self-proficiency can be done in many ways such as self-learning, asking seniors, continuing study to a higher level, and so on.

\subsubsection{Influence of Policy Implementation toward Coor- dination between Regional Work Units in Realizing Dis- aster Management Effectiveness}

The extent of the influence of disaster management policy implementation has a significant effect on coordination between Regional Work Unit in realizing the effectiveness of disaster management according to determination coefficient $\left(R^{2}\right.$ YZX) of 0.6215 while the remaining $37.85 \%$ is influenced by other variables not researched. This value indicates that the effect of total implementation of disaster management policy $(\mathrm{X})$ on coordination between Regional Work Units (Y) in realizing the effectiveness of disaster management $(Z)$ is 0.6215 . The test result shows that organizational factors of policy executor, the interpretation of policy executors and policy application determine the coordination between Regional Work Units that will ultimately have an impact on the effectiveness of disaster management.

The results of the study field showed that the implementation of disaster management policy affected coordination. Both factors are interrelated to one another where the policy implementation 
can be properly conducted if the coordination works effectively. Conversely, effective coordination will ensure the policy implementation. In this case, Regional Work Unit in Garut District has made coordination in the form of meetings, training, work shop, and perform communication with a variety of channels. This given coordination is expected to create cohesiveness between the policy executors and the community, village and sub-district officials, education and business institutions resulting in cooperation among stakeholders in preventing disaster so that the implementation of disaster management policy can work well.

Based on field observations it was stated that the effectiveness of the disaster management was not only affected by the implementation of disaster management policy but also influenced by coordination between the Regional Work Units. As it has been noted above, the coordination was done in the form of meeting, workshop, training, and communication through various communication channels such as telephone, mobile phone and correspondence. The all meetings, workshops, and training were conducted to increase community capability to cope with disasters, create resilient villages and sub-districts to disaster, and prepare competent, reliable and dedicated executors of disaster management. The whole coordination effort was carried out to make the indivisibility and harmony among all stakeholders in order to realize the effectiveness of disaster management.

In addition, the results of field observations showed that the implementation of disaster management policies has affected to the effectiveness of disaster management policy. In implementing disaster management policy, Regional Work Unit of Garut District has been supported by the human resources as the executors of the policy, but it still requires additional quantity and competence of human resources. Despite its limited human resources, the Regional Work Unit of Garut already implemented various development programs and disaster management socialization involving elements of society, education institution, village and sub-district officials and business institutions. Likewise, in the policy application, Regional Work Unit of Garut already has guidelines for disaster relief in the form of clear technical instructions. However, in terms of supporting mobility Regional Work Unit of Garut still require additional quantity.

In addition to the implementation of policy and coordination, the variable of the effectiveness of disaster management is also influenced by other factors (epsilon). The test result showed that the influence of other factors not examined was $37.85 \%$. The factors consist of the managerial, behavioral, cultural and organizational atmosphere. The effectiveness of disaster management will be realized if supported by a qualified disaster management and conducive behavioral, cultural, and organizational atmosphere.

\subsubsection{Influence of Policy Implementation to Coordina- tion between Regional Work Units}

The implementation of the policy will work properly when it is done under coordination with relevant parties. The extent of the policy implementation effect on coordination between Regional Work Unit is $76.97 \%$, while the remaining $23.03 \%$ is influenced by other variables outside coordination variables not involved in the model (epsilon).

Based on observations and interviews with the Head of Regional Work Unit in Garut it was noted that heads, staffs and related parties elements of leadership have made in-depth coordination regarding disaster management through organizing coordination meetings, workshops, training, visiting and direct dialogue with the involved parties, as well as coordination with various communication channels, but the research finding showed that there are other variables besides coordination variables that can support policy implementation. Communication is an important and primary factor in implementing coordination, and effective communication can reach consensus in solving the problem. The consensus is the meeting point of understanding between the different parties so that all interests can meet in an agreement ${ }^{8}$.
The other variable (epsilon) seen to affect coordination is workability. Qualified employee will have the ability and enough time to make coordination because he is able to perform other tasks in addition to faster coordination than other employees. In this regard, ${ }^{9}$ stated that someone who has qualifications to do some particular activities may participate in certain activities, including the activities of an organization, and a person's ability to work are extensive knowledge mastery and high skills. Although knowledge and skills are the attributes of a person, in fact, knowledge and skills also belong to an organization that uses them or in other words the organization has purchased them from its members to achieve organizational goals.

\subsubsection{Influence of Policy Implementation to the Effec- tiveness of Disaster Management}

From the testing it is known that the influence of policy implementation variable to a variable of the effectiveness of disaster management is low by $36.33 \%$ and the remaining $63.67 \%$ is influenced by other variables not examined (epsilon).

Based on field observations, the low influence of policy implementation variable to the variable of effectiveness of disaster management occurred because of the following factors: even though the employees in Regional Work Unit of Garut District have implemented policies properly supported by quite clear technical instructions and equipped by enough work means, and work in accordance with their respective duties based on their head's guidance and direction, there are other factors that affect the effectiveness of disaster management.

Based on the researcher's observations, there are other variables (epsilon) which seem to affect the effectiveness of Disaster Management namely, not the optimal management of the community participation in times of disasters and mental factor. Good management of public participation will make the existing aid maximally used and well distributed to victims and disaster area so that disaster management works effectively. In addition, mental factor influences the effectiveness of disaster response, someone with healthy mental will be able to adapt to his environment, utilize his potential, have self-confidence, and get responsible for the task he gains. All the mental factors will shape capable people mentally and intellectually so that they can devote themselves to the organization.

\subsubsection{Influence of Coordination between Regional Work Units to the Effectiveness of Disaster Management}

From the testing result, it is known that the influence of coordination between Regional Work Units to the Effectiveness of work Achievement of Public Welfare Administration Division is 0.2582 or $25.82 \%$ and the remaining $74.18 \%$ is not included in the model. This low influence shows that the effectiveness of disaster management is not only influenced by coordination.

Based on the result of field observations, Regional Work Unit of Garut District has conducted a variety of activities that involved various elements of society in making coordination. This coordination raises awareness to work together and help each other, this is evidenced by the statement "you see and know that all team members and stakeholders of Disaster Relief in Garut always help each other" in the coordination variable between Regional Work Unit that has the highest percentage

e of the other items of coordination variables. However, there is another variable that affects the effectiveness of disaster management.

Based on the researcher's observations, there is another variable (epsilon) which seems to affect the effectiveness of disaster management namely managerial factor. This is in line with the results of research measurement instruments in the statement "you see and know that the executives of Regional Work Unit are always capable of setting a work schedule in case of disasters in Garut" and the other statement "you see and know that the Disaster Management in Garut always set disaster management 
priorities" in coordination variable that has the lowest percentage of other items namely $59.73 \%$.

To researchers' concern, scheduling and implementing priority scales are the aspects of managerial factors that influence the effectiveness of disaster management. In addition, employee empowerment and human relations are assumed to influence the effectiveness of disaster management. In this regard, ${ }^{10}$ suggests that employee's empowerment and work responsibility are returned back to the employees. Employees are taught how to monitor their own work and work in teams. They learn to collect and interpret their own work performance data, make any necessary adjustments to the ongoing work, as shown by the collected data. Thus employees gain greater motivation in their work, because they are responsible for their own work, and organizations gain significant savings by removing the level of management that does not give added value for customers. Human relations is also assumed to influence the effectiveness of disaster management because, through human relations approach, employees in organizations and other parties involved with the organization can work together to achieve organizational goals.

\section{Conclusion}

The research findings showed that the implementation of disaster management policy has a positive and significant effect on the coordination between Regional Unit Work in realizing the effectiveness of disaster management.

\section{References}

[1] Farida R, Ramdhani MA. Conceptual Model of the Effect of Environmental Management Policy Implementation on Water Pollution Control to Improve Environmental Quality. Int $J$ Sci Technol Res. 2014;3(10):196-199.

[2] Ramdhani A, Ramdhani MA, Amin AS. Writing a Literature Review Research Paper: A step-by-step approach. Int J Basic Appl Sci. 2014;3(1):47-56. doi:10.2139/ssrn.1954824.

[3] Ramdhani A, Ramdhani MA. Konsep Umum Pelaksanaan Kebijakan Publik. J Publik. 2017;Vol. 11; N:1-12.

[4] Tsabit A, Ramdani MA, Cahyana R. Pengembangan Ganesha Digital Library Untuk Membuat Situs Jurnal. J Algoritm. 2012;9(1):1-10.

[5] Slamet C, Rahman A, Ramdhani MA, Darmalaksana W. Clustering the Verses of the Holy Qur'an Using K-Means Algorithm. Asian J Inf Technol. 2016;15(24):5159-5162.

[6] Pamoragung A, Suryadi K, Muhammad Ali R. Enhancing the Implementation of e-Government in Indonesia through the HighQuality of Virtual Community and Knowledge Portal. In: 6th European Conference on E-Government. ; 2006:341-347.

[7] Bustomi Y, Ramdhani MA, Cahyana R. Rancang Bangun Sistem Informasi Geografis Sebaran Tempat Riset Teknologi Informasi Di Kota Garut. J Algoritm. 2012;ISSN : 230:1-7.

[8] Ramdhani MA, Suryadi K. Consensus method development on analytic hierarchy process. In: ICoQSIA. ; 2005:6-8.

[9] Iskandar J. Manajemen Publik. Bandung: Puspaga; 2016.

[10] Iskandar J. Metode Penelitian Administrasi. Bandung: Puspaga; 2015. 